\title{
Obituary Jacques Ginestié
}

\author{
Marc de Vries ${ }^{1}$
}

๑) Springer Nature B.V. 2020

By the editor

On September 29, 2020, our dear colleague dr. Jacques Ginestié passed away at the age of 67 years. Dr. Ginestié has served as a member of the editorial board of this journal almost from its beginning. His death means a great loss to the international technology education community. Jacques played a leading role in the development of technology education research and teacher education in France. He founded the GESTEPRO group at the University of Aix-Marseille and under his leadership this group made significant contributions to theory and practice of technology education. He was also the prime organiser of one of the international Pupils' Attitudes Towards Technology (PATT) conferences, held in Marseille in 2015. Also he was active in establishing relations between technology educators in the Aix-Marseille region and in Northern Africa through the international RAIFFET network. Our condolences are for his wife, Marjolaine Chatoney, who was and is also a member of the technology education researchers and teacher educators group at Aix-Marseille, and also for his children Edouard and Anouk. We mourn with them for the loss of a wonderful person. He was always enthusiastic, warm, and his laugh could be heard from a distance. We will miss him dearly at our international gatherings. We are comforted by the fact that his wife is still among us and through her presence, his remembrance will be ensured for the years to come.

Publisher's Note Springer Nature remains neutral with regard to jurisdictional claims in published maps and institutional affiliations.

Marc de Vries

M.J.deVries@tudelft.nl

1 Delft University of Technology, Delft, Netherlands 